\title{
REPORT
}

\section{Student Needs Are Academic Needs \\ Community College Libraries and Academic Support for Student Success}

September 30, 2019

Melissa Blankstein, Ithaka S+R

Christine Wolff-Eisenberg, Ithaka S+R

Braddlee, Northern Virginia Community College
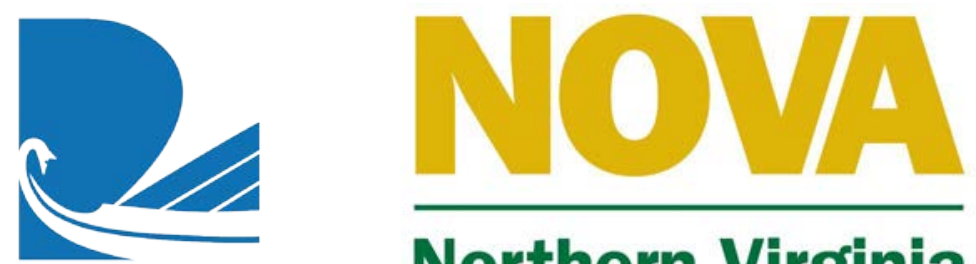

Northern Virginia Community College 


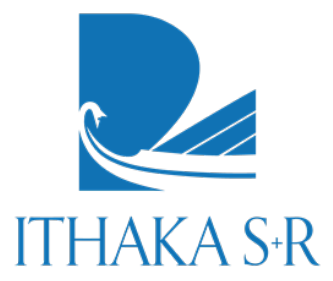

Ithaka S+R provides research and strategic guidance to help the academic and cultural communities serve the public good and navigate economic, demographic, and technological change. Ithaka S+R is part of ITHAKA, a not-for-profit organization that works to advance and preserve knowledge and to improve teaching and learning through the use of digital technologies. Artstor, J STOR, and Portico are also part of ITHAKA.

\section{NOVA| Northem Virginia}

Northern Virginia Community College is the largest institution of higher education in the Commonwealth of Virginia and one of America's largest community colleges. NOVA enrolls more than 75,000 students at its six campuses in Alexandria, Annandale, Loudoun, Manassas, Springfield and Woodbridge, and through NOVA Online. For more information about NOVA and its programs or services visit the College's Web site, www.nvcc.edu.

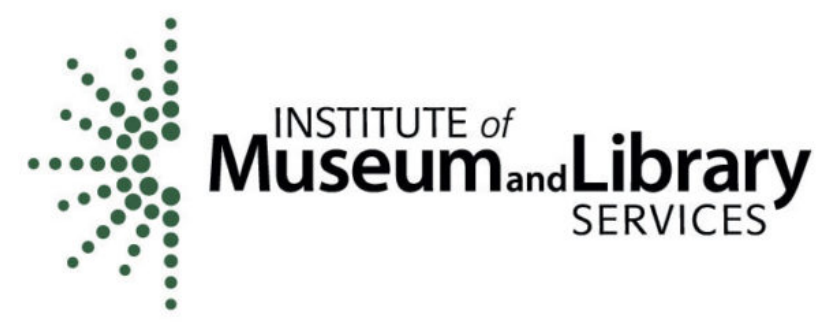

This project was made possible in part by the Institute of Museum and Library Services RE-96-170113-17.

The Institute of Museum and Library Services is the primary source of federal support for the nation's libraries and museums. We advance, support, and empower America's museums, libraries, and related organizations through grantmaking, research, and policy development. Our vision is a nation where museums and libraries work together to transform the lives of individuals and communities. To learn more, visit www.imls.gov and follow us on Facebook and Twitter.

Copyright 2019 ITHAKA. This work is licensed under a Creative Commons Attribution 4.0 International License. To view a copy of the license, please see https:// creativecommons.org/licenses/by/4.0/. ITHAKA is interested in disseminating this brief as widely as possible. Please contact us with any questions about using the report: research@ithaka.org. 


\section{Table of Contents}

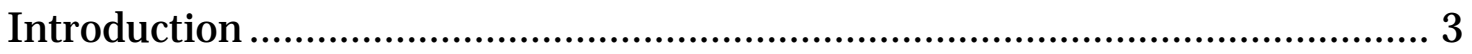

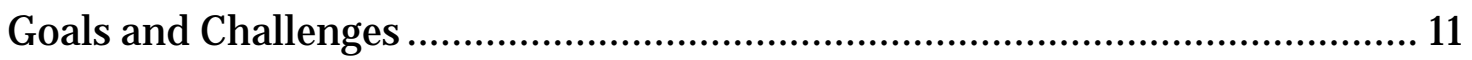

Curricular and Non-Curricular Information Needs........................................21

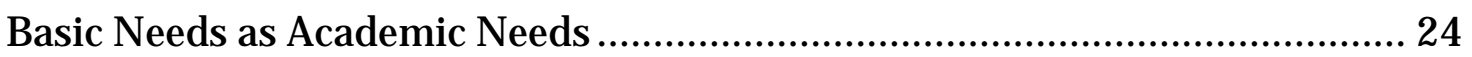

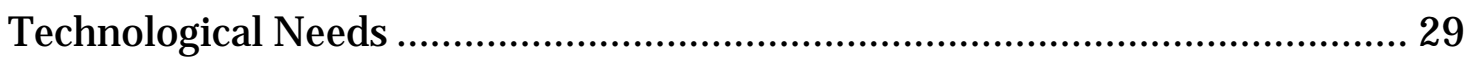

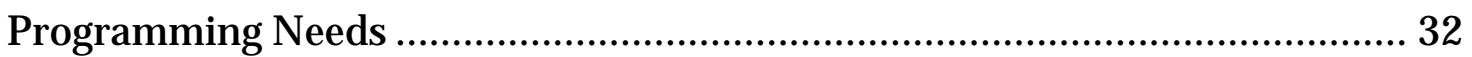

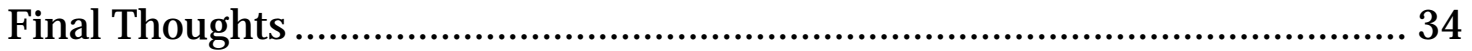

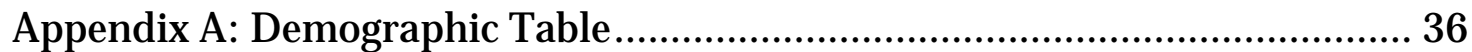

Appendix B: Service Concept Valuation ............................................................. 39 


\section{Introduction}

The Community College Libraries and Academic Support for Student Success (CCLASSS) project examines student success from the perspective of students themselves, what challenges they face in achieving it, and what services can be developed to effectively support them in their attainment of that success. In fall 2018, we surveyed 10,844 students across seven community colleges to assess the value of and demand for proposed services designed to address students' expressed goals, challenges, and needs.

\section{Key Insights}

- Student needs are academic needs. Students often struggle with balancing their personal, professional, and academic responsibilities, including affording their most basic needs in conjunction with course expenses. While many of their most significant challenges take place outside of the classroom, these difficulties nonetheless can have a substantial impact on their academic success.

- Students view college both as a means to an end and as having intrinsic value in and of itself. They highly value both their attainment of knowledge and the advancement of their career as a result of their community college experiences.

- Not all students struggle equally or desire the same support services. Students who have been historically underserved or disadvantaged - such as students of color, first generation college students, those with marginalized gender identities, and those who are low-income, among others - often report encountering greater challenges throughout their college experience and would value potential new services more than their peers.

- The library, academic advising office, and tutoring or writing center are highly valued as service providers in addressing unmet needs. When given a list of possible institutional providers for new services, students frequently named the library as the most promising source of support.

- Students would highly value services to address both their curricular and non-curricular information needs. Students would greatly value inperson services to address challenges related to finding information for navigating college and for completing coursework.

- Student parents want more support with childcare. Parents and guardians, especially women, would highly value childcare services at their college, such as regular or emergency care, and would frequently use these services to ameliorate difficulties with balancing family, household, work, and school responsibilities. 
- Students need greater access to technology. Students are particularly interested in long-term access to Wi-Fi hotspots, printers, laptops, and multimedia editing tools, and would use these devices either at home or on-site for academic, professional, and personal purposes.

\section{The CCLASSS project}

The vast majority of research to date on how to adapt library services to support institutional priorities has been conducted at four-year colleges and universities. The definitions of student success used in these projects have often derived from higher education institutions, state boards of education, and the federal government, thus omitting the valuable perspective of the student in what defines success. To continue evolving in support of their students, community colleges and their libraries need strategic intelligence about how to adapt their services.

Through the Community College Libraries \&Academic Support for Student Success (CCLASSS) project, we aim to (1) examine student goals, challenges, and needs from the student perspective, (2) develop a series of services that target these expressed goals, challenges, and needs, and (3) test the demand for these service prototypes. This project, co-led by Northern Virginia Community College and Ithaka S+R, along with six other community college partners and support from the Institute of Museum and Library Services (IMLS) [RE-96-17-0113-17], focuses on strengthening the position of the community college library in serving student needs.

This report discusses the findings from the third and final phase of the multi-year, library-led project. This "assessment phase" consisted of a survey instrument distributed to students at an array of community colleges to evaluate service concepts generated in the previous "development phase" of the CCLASSS project. 


\section{Qualitative discovery}

Learn about the practices, preferences, and needs of community college students and their relationship to success by means of on-campus, in-depth, inperson qualitative interviews

\section{Service concept development}

Develop a series

of concepts for

services that

community

colleges and

their libraries

might seek to

offer based on

the discovery

phase
Survey assessment

Evaluate the service concepts with community college students by means of a survey to determine their potential value

From the discovery phase of the project, which included interviews with 37 students from seven community colleges, we found that, across institutions, students: ${ }^{1}$

- View community college as an accessible option - in terms of location, transportation options, and cost - that fits their complex lives and needs.

- Have complex definitions of success that focus on both their career and educational achievement as well as their personal development.

- Face significant challenges related to balancing work and school, finances, childcare arrangements, language barriers, transportation to and from the college, and navigating resources and services at their college.

- Complete their coursework in a variety of places depending on their individual needs and resources available, generally seeking to avoid distractions and noise.

- Do not find it difficult to locate the information they need for their coursework and have a particular affinity for using Google when doing so. They tend to rely heavily on their professors for providing guidance on resources to use when completing assignments.

These findings substantially guided our creation of eight distinct "service concepts," which we define as hypothetical prototypes of services that colleges might offer to students for specific purposes relevant to the goals, challenges, and/ or needs expressed in the first phase of the CCLASSS project. These service concepts were developed through a collaborative, iterative process with project leads at seven partner community

${ }^{1}$ Full report of findings: Christine Wolff-Eisenberg and Braddlee, "Amplifying Student Voices: The Community College Libraries and Academic Support for Student Success Project," Ithaka S+R, 13 August 2018, https://doi.org/10.18665/sr.308086. 
colleges and three project advisors. This development process began with an in-person meeting where ideas for new services were brainstormed and broadly conceptualized. These services were then prioritized against interview findings, drafted, and finally, tested with students. ${ }^{2}$

We refer to the finalized service concepts with the following short names throughout this report: Social Worker, Loaning Tech, Child Care, Community Advocacy, Privacy, Knowledge Base, Personal Librarian, and Student Showcase. These short names were not disclosed to students; a full description of each concept as it was presented to students is provided below (see Table 1).

The purpose of the survey assessment phase primarily is to determine what service concepts would be of the greatest value for community college students, potential demand among different populations, the frequency with which students might use these new services, and where they would most likely use them. This phase also examined students' personal, academic, and professional goals as well as the challenges they face throughout their college experience.

\footnotetext{
${ }^{2}$ For more information on our service concept development, see our forthcoming issue brief: Christine Wolff-Eisenberg and Roger C. Schonfeld, "Service Development for Libraries," Ithaka S+R, Forthcoming 2019.
} 


\title{
Table 1. Service concepts and their descriptions as displayed to respondents in order of highest to lowest rated value.
}

\author{
Service Concept \\ Short Name
Knowledge Base Imagine that the college offered a single point of contact for whenever you need help navigating any part of college including advising, registering for classes, applying for financial aid, securing personal counseling, and obtaining tutoring or other coursework assistance. This service would offer expertise in connecting you with the right college employee for assistance. \\ Loaning Tech Imagine that there was a place at your college where you could access technology either to \\ borrow for use outside class and at home, or use on-site with expert training and assistance. \\ The equipment available might include options such as a 'one-touch studio' for recording video \\ presentations, 3-D printers, large-format poster-size printers, virtual reality headsets, multimedia \\ editing computers and software, digital audio/video recorders, laptops, tables, chromebooks, \\ scientific calculators, Wi-Fi hotspots, and black/white or color printers for on-site use and/or \\ checkout.
}

Personal Librarian Imagine that a dedicated professional employed by the college would be available to help you find and use all kinds of content sources you might need for your coursework, including books and journals, in paper, and on the internet. This professional would provide help in person or via email, phone, or chat on any assignment.

Social Worker Imagine that a social worker was readily available at your college to help you any time you needed personal assistance. Depending on your needs, they could assist you with finding housing, securing childcare, finding reliable transportation, seeking public assistance, and/or navigating other life challenges. The social worker would offer drop-in hours, and they would also be "on call" if you had a personal emergency during non-working hours.

Child Care Imagine that there were an array of services at the college to accommodate students who have children of their own or are caregivers while you are attending class. These services might include designated spaces for families to study together, both regular and emergency childcare programs, and tutoring and other afterschool services for children.

Imagine that there was a workshop you could take about how to operate effectively and safely
in today's digital world. This would include a practical guide on how to choose which digital
services to use, how to encrypt sensitive communications, and how to delete your activity trail
and presence. Each student would be guided in finding the right balance between using
personalized services and the privacy interests that these services may minimize.

Community Advocacy Imagine the college made available opportunities that would help you better develop your capacity as a member of your community and society. These could include one-time presentations by faculty, members of community groups, industry experts, or fellow students, and can take the form of workshops, ongoing discussion groups, informal meetups, or online resources. Rather than seek to educate you on particular political perspectives, the goal would be to help you develop your own perspective and strategies for engagement, so you could participate on issues that are important to you as a citizen, an informed member of society, an activist, or whatever other role you choose to assume.

Student Showcase Imagine that the college offered you and fellow students an opportunity to publicly display work from your classes, or to contribute personal and professional expertise developed outside of classes, through various displays, presentations, workshops, and more, either in person or virtually. You would have a space in which you could gather with other students to share your experience, expertise, and work, as well as learn from other students. 


\section{Methodology}

The population for this survey is currently enrolled, credit and non-degree/ workforce students over the age of 18 among seven community colleges. Four colleges are located in different boroughs of New York City; the remaining three are located elsewhere in New York state, Virginia, and Washington. Each college serves a highly diverse population of students. ${ }^{3}$

The survey was pre-tested in order to ensure that it was understood clearly and consistently across respondents. Eight in-depth cognitive interviews were conducted in September 2018 with students from two of the colleges involved in the project.

The finalized survey was fielded between October and December 2018. Each college submitted contact lists of up to 15,000 students to Ithaka S+R. Although this project was library led, a customized version of the survey was distributed to students at each college via the survey platform Qualtrics under the signatory of the college provost, vice president of academic affairs, or equivalent. Among the participating colleges, 93,637 students received an email invitation to participate in the survey, and 10,8444 students completed the survey for an overall response rate of about 12 percent. ${ }^{5}$ As an incentive for participation, respondents were entered into a raffle to win one of ten $\$ 100$ Amazon or Visa gift cards per college campus, and 70 gift cards were distributed. ${ }^{6}$

Following questions on their goals and challenges, respondents were presented with descriptions of service concepts that might be offered at their college. These service concept descriptions and corresponding exploratory questions were presented in a random order to each respondent to decrease any potential bias resulting from recency or primacy effects. Short names for each service concept were generated for reporting purposes; these were not presented to respondents (see Table 1).

Additionally, respondents did not receive every question within the survey. Of the eight service concepts, each respondent received four randomly selected concepts within their

\footnotetext{
${ }^{3}$ See Appendix A for further demographic information on survey respondents.

${ }^{4}$ Margin of error is 1 percent for $n=10,844$ at the 95 percent confidence level.

${ }^{5}$ We intend to deposit the underlying dataset as part of the Ithaka S+R Surveys of Higher Education Series with ICPSR (https://www.icpsr.umich.edu/icpsrweb/ICPSR/series/226) for long-term preservation and access. Please contact research@ithaka.org if we can provide any assistance in accessing and working with the dataset.

${ }^{6}$ For more information on our survey administration practices, see our forthcoming report: Nicole Betancourt and Christine WolffEisenberg, "Surveying Community College Students: Strategies for Maximizing Engagement and Increasing Participation," Ithaka $S+R$, Forthcoming 2019.
} 
questionnaire to reduce survey duration. If the respondent indicated that the service concept would be of any value, they were presented with a series of follow up questions related to that service concept. If the respondent indicated that the service concept was not valuable at all, additional questions were skipped and the next, randomly ordered service concept was displayed.

Perceived value for each service concept was measured on a five-point scale from "not at all valuable" to "extremely valuable." Responses within this report highlight respondents who indicated each service concept as "extremely valuable" in order to demonstrate perspectives of students who we can expect to be most likely to need and use these services. For subgroup comparisons, reported differences below are significant at the .05 level or lower. Subgroups with under 300 respondents were included in the aggregate analysis, but generally omitted from subgroup analysis due to their size. ${ }^{7}$

\section{Acknowledgements}

Each of the colleges involved in this project is represented by a project lead who serves as a point person for their local institution, helping to ensure that decisions made in this project will be strategically valuable to community colleges and their students. This team played a vital role in developing the library service concepts and survey instrument, preparing for the administration of the survey at their college, and implementing one or more of the service concepts:

- J ean Amaral, Associate Professor/ Open Knowledge Librarian, Borough of Manhattan Community College

- Braddlee, Dean of Learning \& Technology Resources, Northern Virginia Community College, Annandale Campus

- Christie Flynn, Dean of Library and Learning Resources, Pierce College District

- J eanne Galvin, Professor and Chief Librarian, Queensborough Community College

- Katie Ghidiu, Director of Library Services, Monroe Community College

- Michael Miller, Professor and Chief Librarian, Bronx Community College

- Steven Ovadia, Professor and Deputy Chief Librarian, LaGuardia Community College

- Silvia Lin Hanick, Reference and First Year Experience Librarian, LaGuardia Community College

${ }^{7}$ See Appendix A: Demographic Table for further demographic information on survey respondents. 
In addition to the project leads, we convened an external advisory panel to provide guidance at critical points in the project:

- Bryan Alexander, Senior Scholar, Georgetown University and President, Bryan Alexander Consulting

- Debra Gilchrist, Vice-President for Learning and Student Success for Pierce College District

- Megan Oakleaf, Associate Professor, Syracuse University School of Library and Information

We thank the project leads and external advisory panel members for their tremendous contributions towards this project as well as the Institute of Museum and Library Services for providing support to make this project possible [RE-96-17-0113-17].

We are immensely grateful to Nicole Betancourt who led the administration of the student survey. This project would not be possible without her substantive contributions. We also thank Roger Schonfeld, Co-Principal Investigator, for his leadership and substantial contributions towards service concept development; J anet Oberla, Grant Project Manager, for her role in facilitating the project across seven partner colleges and Ithaka S+R; and Kimberly Lutz for her input on this report. 


\section{Goals and Challenges}

Community college students were initially queried on their academic, personal, and professional goals, as well as potential challenges they may face. Overall, students rate goals related to obtaining knowledge and advancing their professional career as the most important outcomes for their college experience. Students have also clearly signaled the significance of challenges stemming from balancing their personal, academic, and professional lives, including their ability to afford basic needs on top of their course expenses.

Specific goals and challenges vary by different student subgroups within the sample. Libraries and their institutions may need to focus their efforts on targeted populations to address their unique challenges, goals, and needs, and ultimately create equitable outcomes for all students. About 75 percent of respondents indicated they are currently working, and 31 percent are working full time. About 32 percent of the sample indicated they were not born in the US, and 56 percent indicated that at least one of their parents did not complete a college or university degree. Approximately 45 percent of respondents are receiving or are currently eligible for a Federal Pell Grant. ${ }^{8}$ The median respondent age is 23; half of respondents are between the ages of 18 and 22, about 28 percent are between the ages of 23 and 30, 13 percent are between 31 to 40, and nine percent are 41 years old or older. Lastly, about 16 percent identify as Asian, 20 percent as black or African American, 28 percent as Hispanic or Latinx, and 34 percent as white.

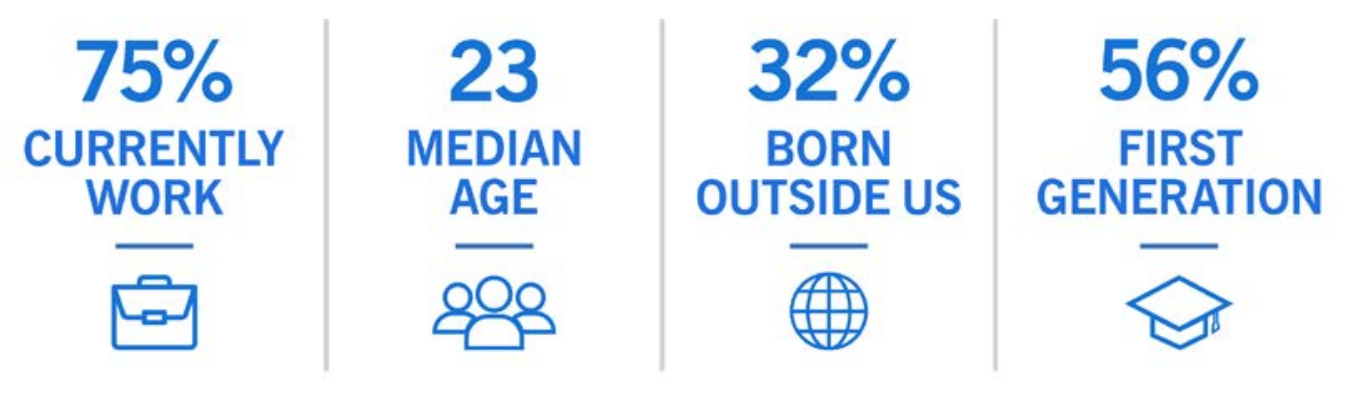

${ }^{8}$ About 31 percent are unsure if they have received a Pell grant or are currently eligible, and 25 percent have not received one or are currently ineligible. It may be possible that not all students know the name of the funding source from which they are receiving aid. 
Overall, students who have been historically underserved and/ or disadvantaged find challenges throughout their college experience to be more difficult than their peers. ${ }^{9}$ This report takes an in-depth look into subgroup responses in order to provide insight on the goals and challenges relating to the community college experience for those who have historically been underserved and/ or disadvantaged, as well as potential demand for new services from these students.

\section{Goals}

The greatest share of students - about six in ten - consider gaining knowledge about a specific subject, major, or career to be an extremely important goal; large shares of respondents similarly view their ability to make more money (57 percent), choose a career or post-graduation plan (54 percent), and advance in their current career (51 percent) as extremely important (see Figure 1). Goals related to socializing and collaborating with other students, such as getting involved in organized extracurricular activities and collaborating on group projects with other students, are relatively less important than goals relating to future endeavors. Overall, the goals articulated in this survey very much align with qualitative findings from the first phase of this project: students see both intrinsic, process-oriented goals and extrinsic, outcome-oriented goals as highly important.

${ }^{9}$ We have defined this population to include but not be limited to first-generation students, low-income students, students of color, students with marginalized gender identities, students not born in the US, and students with dependents. 
Figure 1. How important is it to you to achieve each of the following goals as a result of your experience at this college? Percent of respondents that indicated each goal as extremely important.

Gaining knowledge about a specific subject, major, or career

Being able to make more money

Choosing a career or post-graduation plan

Advancing in my current career

Building my resume with career-related experiences

Transferring to another college or university

Having a specific GPA

Developing a professional network

Developing social skills

Transitioning into a new career field

Gaining general knowledge on many different topics

Improving my ability to find sources of information on a range of topics

Collaborating on group projects or in teams with other students

Getting involved in organized extracurricular activities, such as clubs, sports, campus leadership or committees, etc.
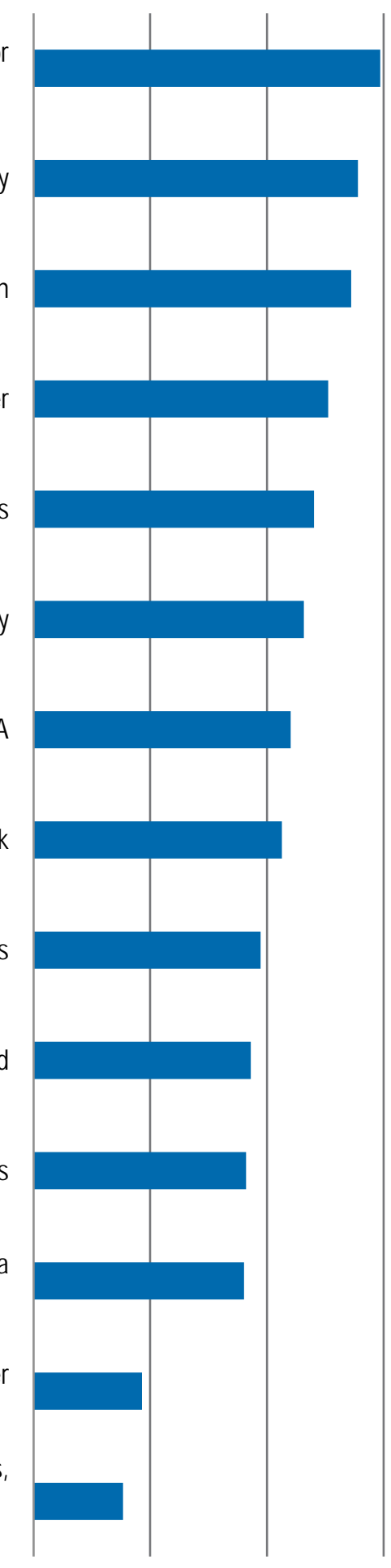

$0 \% \quad 20 \% \quad 40 \% \quad 60 \%$

$80 \%$

$100 \%$ 
While respondents across demographic subgroups are fairly consistent in their valuation of these goals, there are some notable differences that may have implications for service provision. We see that students who are enrolled full time, as well as those who are not parents/guardians of a dependent minor, are more likely to seek to transfer to a different college or university. About five in ten respondents who are enrolled full time at their college rate transferring to another institution as extremely important compared to about four in ten of their part-time enrolled peers. Similarly, five in ten respondents who do not have dependent minors are concerned with transferring compared to about four in ten of their parent/ guardian peers (see Figure 2). Correspondingly, 45 percent of respondents who are parents or guardians rate transitioning into a new career field as extremely important compared to 35 percent of those who are not. Additionally, a greater share of respondents who were not born in the United States rate having a specific GPA, developing a professional network, and developing social skills as extremely important compared to their US-born peers (see Figure 3).

Figure 2. How important is it to you to achieve each of the following goals as a result of your experience at this college? Percent of respondents by parent/guardian status that rated each goal as extremely important.

Transferring to another college or university
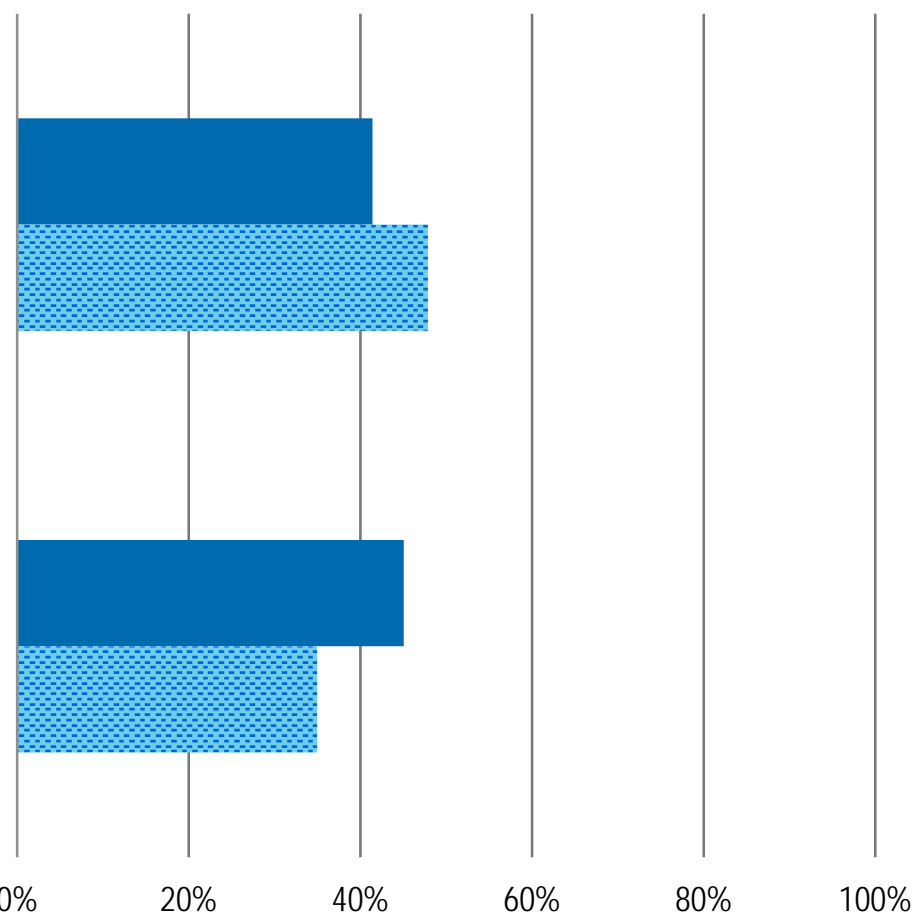

Transitioning into a new career field

$0 \%$

$20 \%$

$40 \%$

$60 \%$

$80 \%$

$100 \%$

- Parent/guardian of a dependent minor

폴 Not a parent/guardian of a dependent minor 
Figure 3. How important is it to you to achieve each of the following goals as a result of your experience at this college? Percent of respondents that were or were not born in the US that rated each goal as extremely important.

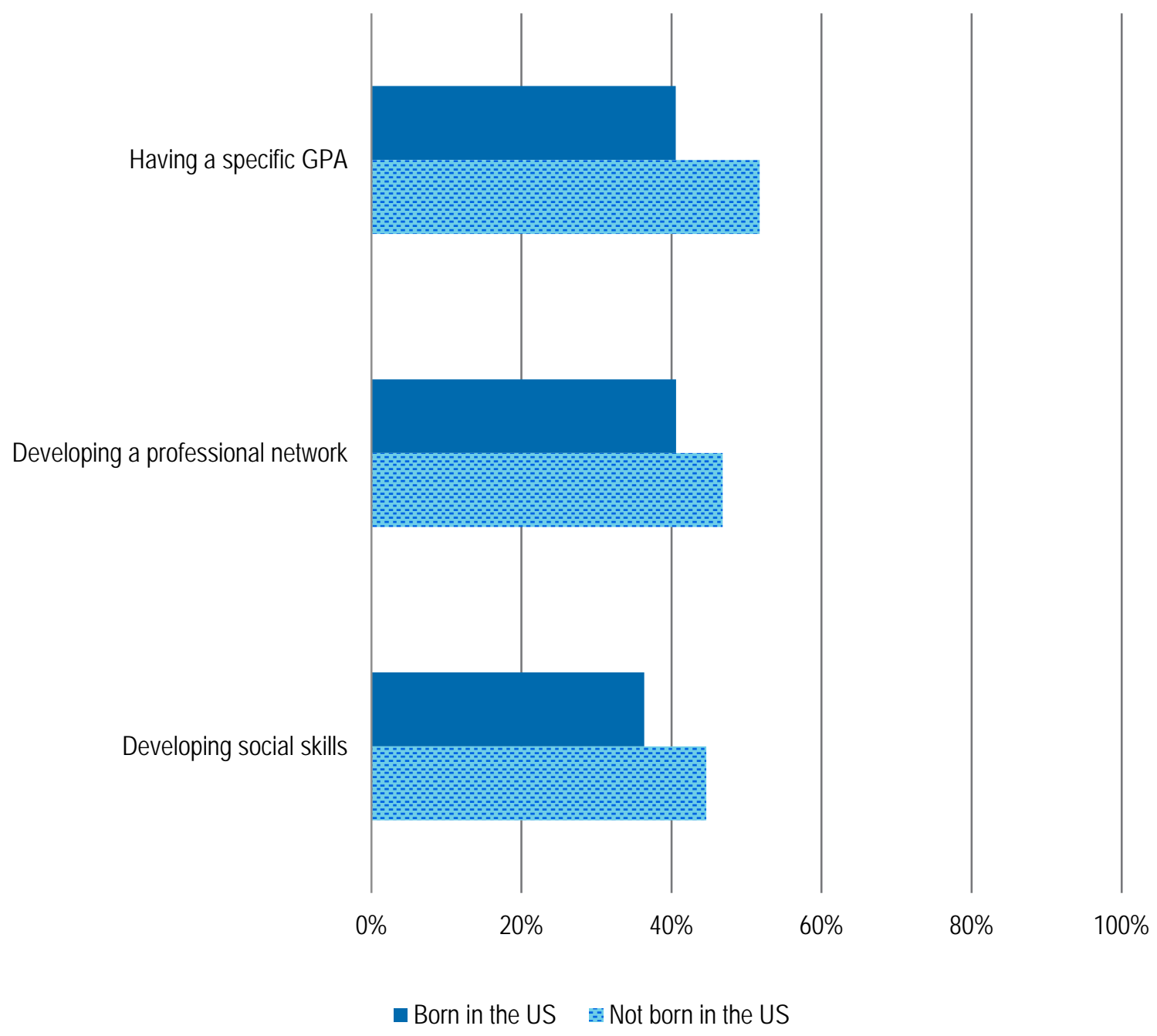




\section{Challenges}

When asked about the relative ease or difficulty associated with accomplishing various activities as a college student, the most pressing challenges often related to noncurricular issues. Fifty-five percent of respondents identified balancing family, household, and school responsibilities as very or somewhat difficult. About 54 percent of respondents rated balancing work and school responsibilities as similarly difficult, followed by having enough money to pay for their basic needs such as housing, food, clothing, and transportation (50 percent), having enough money to pay for their courses (49 percent), and time management (46 percent) (see Figure 4).

Looking specifically at curricular challenges, the highest share of respondents (37 percent) rated writing research papers for class as difficult, followed by getting textbooks and other course materials (29 percent), and completing required courses for their major and/ or program (28 percent). These findings again resonate with our earlier interviewdriven findings in the extent to which students struggle with non-curricular needs. Recent findings in other studies have also documented the extent to which work and financial issues present challenges to community college student success. ${ }^{10}$

In regard to technological needs, approximately 79 percent of respondents report that it is very or somewhat easy to access reliable internet service, and 78 percent similarly have reliable access to a computer, laptop, or similar device. However, further assistance with and seamless access to technological resources, such as Wi-Fi hotspots, was found to be highly desirable, which will be discussed later in this report.

${ }^{10}$ Stephen R. Porter and Paul D. Umbach, What Challenges to Success Do Community College Students Face? Raleigh, NC: Percontor, LLC, January 2019, https://www.risc.college/sites/default/files/2019-01/RISC 2019 report natl.pdf. 


\section{Figure 4. How easy or difficult are each of the following for you? Percent of}

respondents that indicated each as very/ somewhat difficult, excluding those who indicated any item as not applicable.

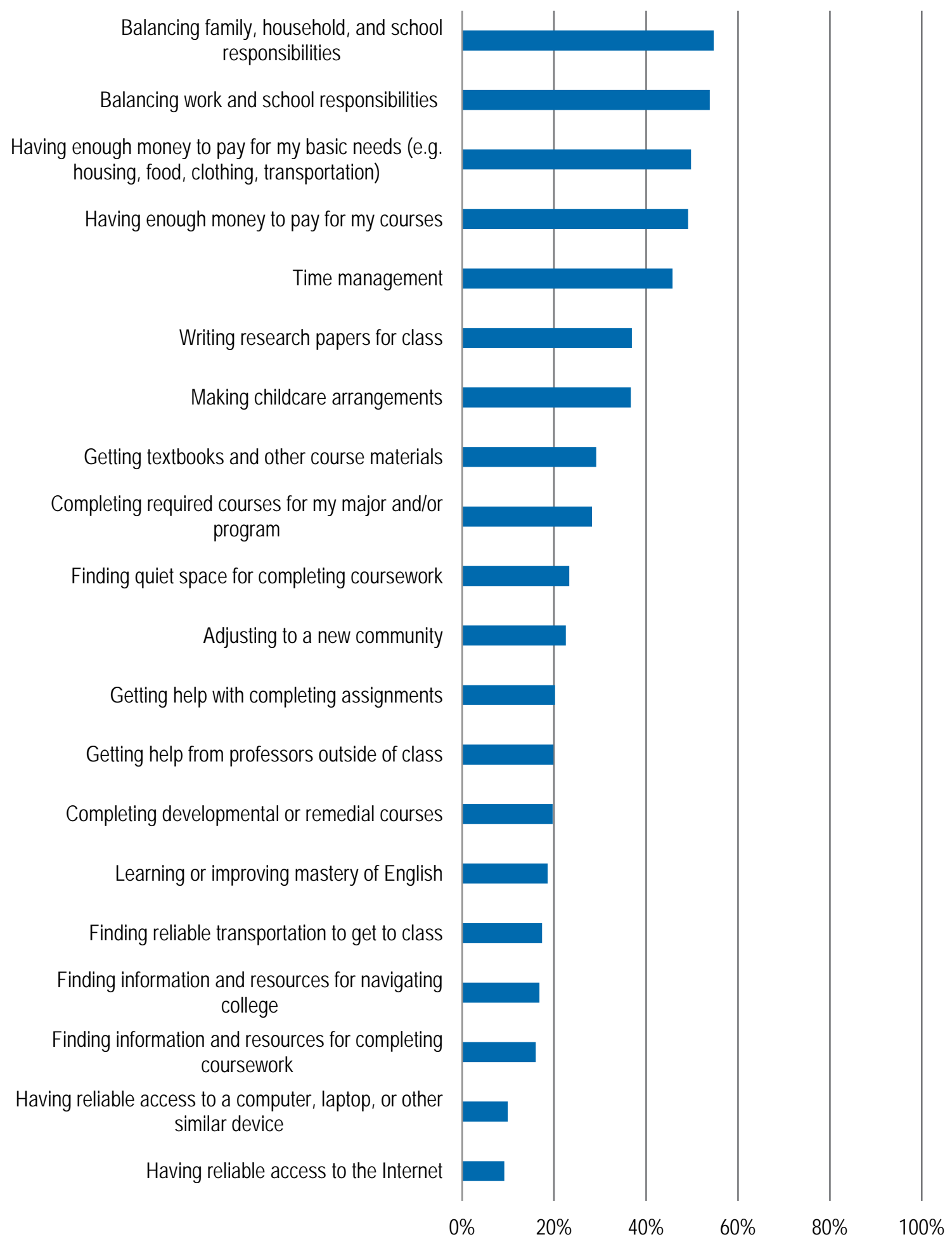


Many of the challenges expressed by respondents in this survey align with ongoing research detailing the increased difficulties students encounter, particularly those who are eligible for Federal Pell Grants, in having their most basic needs met. ${ }^{11}$ About 46 percent of Pell-eligible respondents to this survey indicated difficulty with having enough money to pay for their courses, compared to 54 percent of those who are not Pell-eligible. However, 55 percent of Pell-eligible respondents rate having enough money to pay for their basic needs as difficult, compared to 45 percent of their peers who are not Pelleligible. Difficulties pertaining to paying for courses also vary by enrollment status. Fiftysix percent of part-time students have a hard time finding enough money to pay for their courses compared to 46 percent of their full-time peers.

Colleges and their libraries may also consider the specific challenges facing students in different age cohorts and those with non-binary gender identities. Students between the ages of 23 and 40 find it considerably more difficult to balance family, household, school, and work responsibilities, have enough money to pay for their basic needs and courses, and make childcare arrangements than their younger and older peers (see Figure 5). Further, students who are relatively older (31+years old) have somewhat more difficulty in completing required courses for their major and/ or program, getting help completing assignments, and learning or improving mastery of English. Additionally, approximately four in ten respondents who identify as non-binary rate adjusting to a new community as difficult compared to 23 percent of those who identify as women and 21 percent of those who identify as men.

${ }^{11}$ Sara Goldrick-Rab, Christine Baker-Smith, Vanessa Coca, Elizabeth Looker, and Tiffani Williams, "College and University Basic Needs Insecurity: A National \#RealCollege Survey Report," The Hope Center, April 2019, https://hope4college.com/wpcontent/uploads/2019/04/HOPE realcollege National report digital.pdf. 
Figure 5. How easy or difficult are each of the following for you? Percent of respondents by age that indicated each as very difficult/ somewhat difficult, excluding respondents who indicated any item as not applicable.

Balancing family, household, and school responsibilities

Balancing work and school responsibilities

Having enough money to pay for my basic needs (e.g. housing, food, clothing, transportation)

Having enough money to pay for my courses

Making childcare arrangements
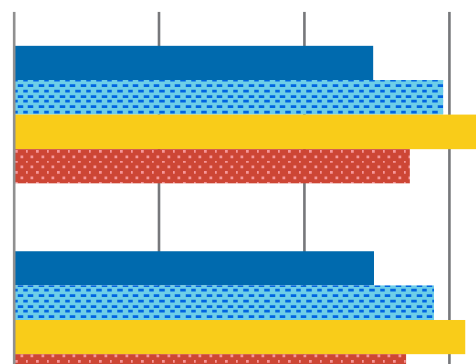

\section{.}
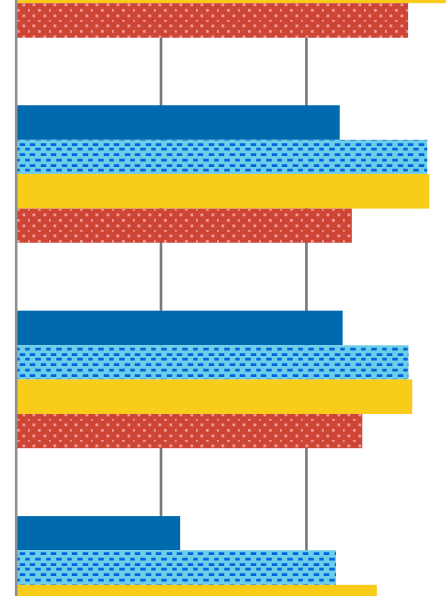

Completing required courses for my major and/or program

Getting help with completing assignments

Completing developmental or remedial courses
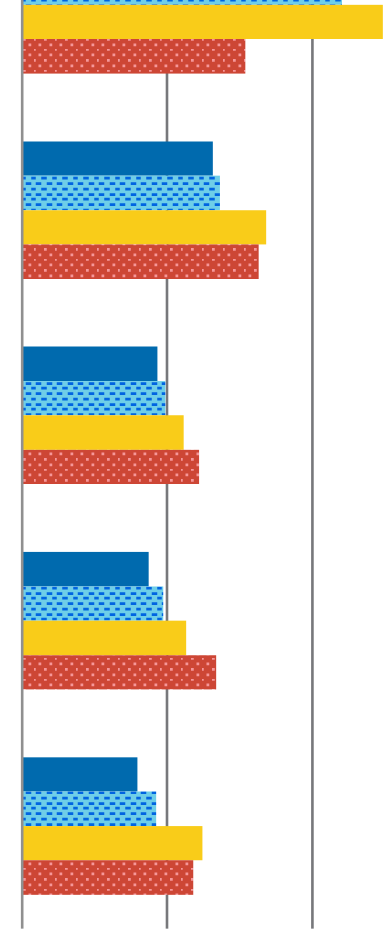

$0 \% \quad 20 \% \quad 40 \% \quad 60 \%$

$80 \%$

$100 \%$

-18-22 $\quad$ : 23-30 $\quad 31-40 \quad$ : $41+$ 
Lastly, those students who identified as black, African American, Hispanic, and/ or Latinx rate balancing family, household, school and work responsibilities, as well as affording their basic needs/ courses, as more difficult than their peers (see Figure 6). Conversely, with the exception of making child care arrangements, white respondents find each of these items less challenging. Asian respondents also do not find some of these items as challenging as their peers, though are more likely to find learning or improving mastery of English and adjusting to their new community to be difficult compared to their peers. Additionally, Hispanic or Latinx respondents rate having enough money to pay for their courses, getting textbooks and course materials, and learning or improving mastery of English as more difficult than their peers.

Figure 6. How easy or difficult are each of the following for you? Percent of respondents by race/ ethnicity that indicated each as very difficult/ somewhat difficult, excluding respondents who indicated any item as not applicable.

Balancing family, household, and school
responsibilities

Balancing work and school responsibilities

Having enough money to pay for my basic needs (e.g. housing, food, clothing, transportation)

Having enough money to pay for my courses

Making childcare arrangements

Getting textbooks and other course materials

Adjusting to a new community

Learning or improving mastery of English

$\begin{array}{cccc}0 \% & 20 \% & 40 \% & 60 \% \\ \text { - Asian } \quad \text { Black or African American } & \text { Hispanic or Latinx } & \text { White }\end{array}$

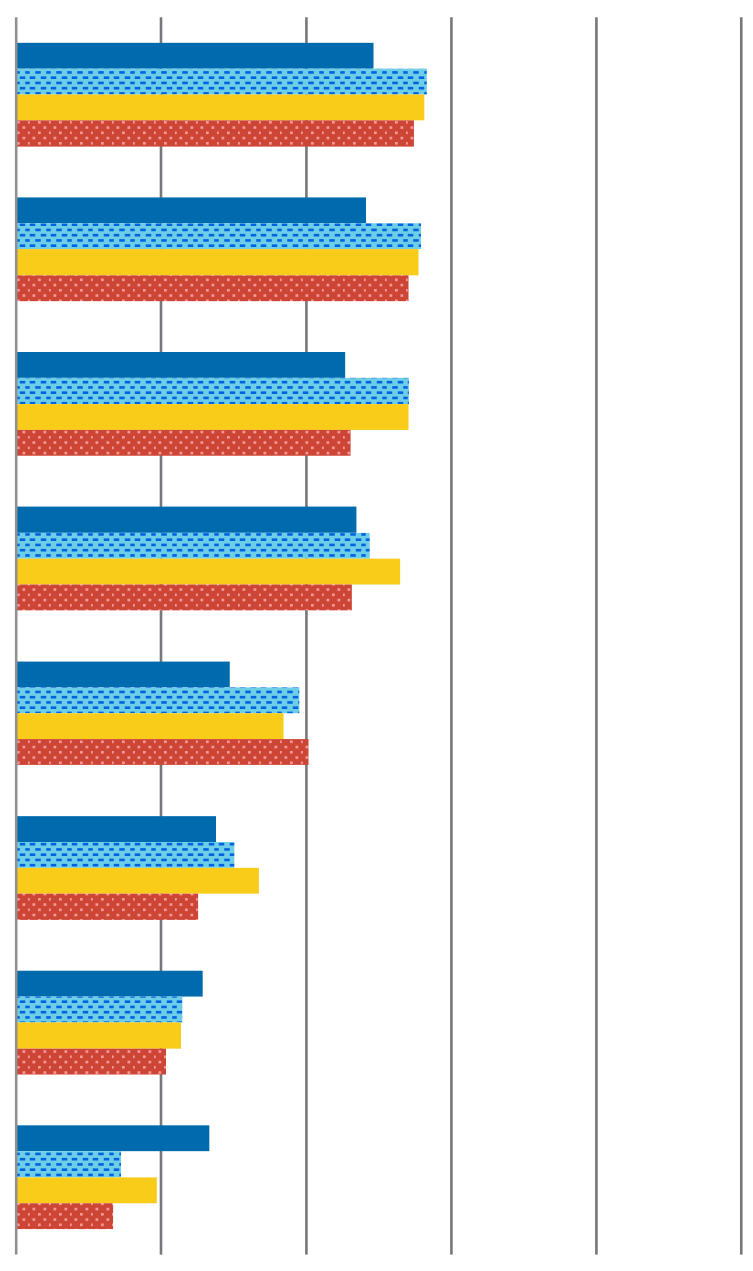

$80 \% \quad 100 \%$ 
From these findings on goals and challenges, we see that community college students value the ability to increase their knowledge to advance their career and make more money, which could ameliorate challenges associated with balancing their family, household, and working lives, and affording their most basic needs. In the following sections of this report, we share findings on services proposed to address and dismantle many of the barriers facing students in achieving success.

\section{Curricular and Non-Curricular Information Needs}

The two service concepts that respondents view as most valuable bridge the gap between their academic and personal goals in support of their informational needs - both curricular and non-curricular (see Appendix B). Approximately 44 percent of respondents saw the Knowledge Base service concept as extremely valuable as did 41 percent for Personal Librarian. The Knowledge Base service would provide students with a single point of contact to help navigate their college (i.e. advise on where to go for advising, registering for classes, financial aid, etc.), ${ }^{12}$ while the Personal Librarian service would provide a dedicated professional to help students find and use materials needed for their courses.

Knowledge Base: Imagine that the college offered a single point of contact for whenever you need help navigating any part of college including advising, registering for classes, applying for financial aid, securing personal counseling, and obtaining tutoring or other coursework assistance. This service would offer expertise in connecting you with the right college employee for assistance.

Personal Librarian: Imagine that a dedicated professional employed by the college would be available to help you find and use all kinds of content sources you might need for your coursework, including books and journals, in paper, and on the internet. This professional would provide help in person or via email, phone, or chat on any assignment.

Not only do these services help students accomplish their primary goal of gaining knowledge on a specific subject, they may also minimize time spent balancing work, family, and school life. As one student mentioned in an interview during the first phase of this project: "I have to find every little bit of time that I can, whether it's 30 minutes or an hour in between things in order to study or finish an assignment and get everything done." Providing one centralized place or individual to help gain information needed to maintain financial aid or locate articles for a research paper could lessen the stress

\footnotetext{
${ }^{12}$ For an example of an existing Knowledge Base-oriented service implemented at a community college see Elizabeth Jardine, "The Library Leading: Knowledge Management Supporting Community College Institutional Strategy," CUNY Academic Works, 2018, https://academicworks.cuny.edu/lg pubs/118.
} 
associated with navigating all of their responsibilities both within and outside of the classroom.

There are few notable differences between subgroups in students' valuation of the Knowledge Base service concept, indicating that this service could be used by a wide array of students. However, about five in ten respondents who identify as black, African American, Hispanic, and/ or Latinx value the Knowledge Base service compared to about four in ten respondents who identify as Asian or white. Additionally, women tend to value both the Knowledge Base and Personal Librarian services notably more than men (47 percent versus 39 percent respectively for Knowledge Base, and 43 percent versus 37 percent respectively for Personal Librarian).

The Personal Librarian service concept is also particularly valued by students who were not born in the United States, are Pell-eligible, have not had one or more parent complete a college or university degree, and identify as black, African American, Hispanic, and/ or Latinx. About 46 percent of respondents who were not born in the US rated Personal Librarian as extremely valuable compared to 39 percent of US-born students. Additionally, 44 percent of Pell-eligible respondents rate this service concept as extremely valuable compared to 37 percent of those who are not; likewise, 44 percent of students who did not have one or more parents complete college value the Personal Librarian service, compared to 37 percent of students whose parents do have a degree. Lastly, about five in ten black, African American, Hispanic, and/ or Latinx respondents find the Personal Librarian service to be extremely valuable, followed by 36 percent of Asian respondents, and 32 percent of white respondents.

When asked how often they would use these informational services, students who rated them as extremely valuable indicated that they would use the Personal Librarian service relatively frequently, while there was more variability in their potential use of the Knowledge Base service (see Figure 7). Respondents also find these services to be particularly valuable if delivered in person: 63 percent of students would find an inperson format for Knowledge Base to be valuable as do 55 percent for Personal Librarian. Forty-eight percent of respondents rate an email format for Knowledge Base valuable, while 44 percent would find an online chat format to be valuable. Forty-four percent of students rate an email format for Personal Librarian as valuable, as did 41 percent for an online chat format. 
Figure 7. How often would you use this service? Percent of respondents that indicated each service as extremely valuable.

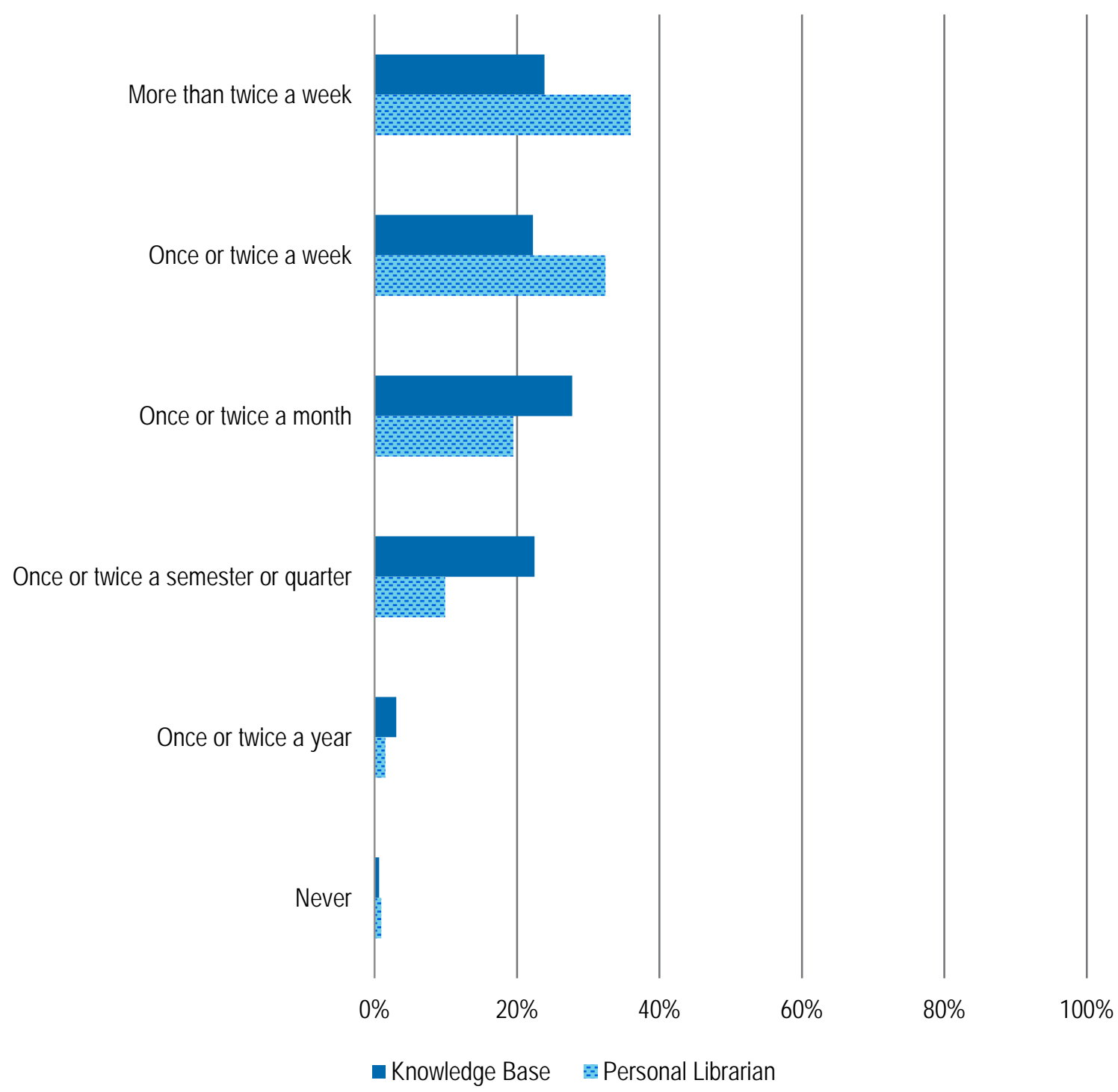

Approximately eight in ten respondents who rated Knowledge Base as extremely valuable would be more likely to use this service if it were provided by their academic advising office or a one-stop center (i.e. location for multiple services including registration, financial aid, bursar, etc.), followed closely by the library ( 74 percent). Similarly, eight in ten respondents who rated Personal Librarian as extremely valuable would be more likely to use this service if their library or tutoring/ writing center provides it, followed by the academic advising office ( 75 percent), and student computer labs, IT helpdesk, or IT office (74 percent). 
The results on these two service prototypes demonstrate that students would broadly value additional support both in navigating the administrative complexity of college and in completing class assignments. They would particularly find these services valuable in an in-person format provided by their library and/ or academic advising office. Services specifically devoted to the navigation of one's college would be particularly useful to a wide array of students, particularly women, while services related to gathering information for one's academic needs would be especially useful to women, non-US born students, and black, African American, Hispanic, and/ or Latinx students.

\title{
Basic Needs as Academic Needs
}

The most difficult challenges for community college students concern balancing personal, professional, and academic responsibilities as well as affording basic needs, such as food, housing, and transportation, alongside coursework costs. Therefore, challenges that students face cannot be sufficiently understood through an examination of their coursework activities alone. As demonstrated by findings outlined above, both curricular and non-curricular challenges are highly important. Two service concepts were designed to ameliorate these challenges: Social Worker, which would help students any time they need assistance navigating their personal, work, and academic lives, and Child Care, which would specifically help students who have children or are caregivers.

\begin{abstract}
Social Worker: Imagine that a social worker was readily available at your college to help you any time you needed personal assistance. Depending on your needs, they could assist you with finding housing, securing childcare, finding reliable transportation, seeking public assistance, and/ or navigating other life challenges. The social worker would offer drop-in hours, and they would also be "on call" if you had a personal emergency during non-working hours.
\end{abstract}

Child Care: Imagine that there were an array of services at the college to accommodate students who have children of their own or are caregivers while you are attending class. These services might include designated spaces for families to study together, both regular and emergency childcare programs, and tutoring and other afterschool services for children.

Approximately 32 percent of respondents rate the Social Worker service concept as extremely valuable. This was especially true for parents/guardians, women, and black, African American, Hispanic, and/ or Latinx students. About 41 percent of parents or guardians rate this service as extremely valuable compared to 30 percent of their nonparent/ guardian peers. Women find this service concept notably more valuable than men, with 36 percent rating Social Worker as extremely valuable compared to 26 percent of men. About 43 of black or African American students, and 40 percent of Hispanic or Latinx students rated this service as extremely valuable, followed by 27 percent of Asian 
students, and 24 percent of white students. Additionally, respondents in their twenties and thirties rate this service slightly more valuable than their peers: 38 percent of 23-30 year olds indicated Social Worker as extremely valuable, followed by 37 percent of 31-40 year olds, as compared to about three in ten students 18-22 or 41 and older.

When asked how often they would utilize the Social Worker service, about 26 percent of those who rated it as extremely valuable said they would use it once or twice a month, 25 percent would use it more than twice a week, 22 percent would use it once or twice a week, and 17 percent would use it once or twice a semester or quarter. Eight in ten students indicated they would be more likely to engage with this service if it were offered through a personal counseling office, followed by 76 percent through an academic advising office, 76 percent through a one-stop center, and 75 percent through a career/job placement office.

Respondents indicated they would use the Social Worker service for addressing a variety of needs. About 44 percent would find this service extremely valuable for finding housing, 42 percent for seeking public assistance and/ or navigating personal and family dynamics, 40 percent for finding reliable transportation, and 33 percent for securing child care. The utilization of these different functions most notably varied by respondents' identified ethnicity, with black or African American students rating these services as relatively more valuable than their peers (see Figure 8). Of the respondents who are Pell-eligible, 46 percent indicated they would use this service for seeking public assistance compared to 38 percent who are not. Additionally, 45 percent of respondents who were born in the US would find this service valuable for navigating personal and family dynamics compared to 36 percent of their non-US born peers, potentially due to the increased stigma of seeking mental health services held by international students. ${ }^{13}$

${ }^{13}$ Daniel Eisenberg, Marilyn Downs, Ezra Golberstein, and Kara Zivin, "Stigma and Help Seeking for Mental Health Among College Students," Medical Care Research and Review 66, 5, October 2009: 522-541, DOI: 10.1177/1077558709335173. 
Figure 8. How valuable would it be for you to have help from a social worker at your college with each of the following? Percent of respondents by race/ ethnicity that indicated each item as extremely valuable.

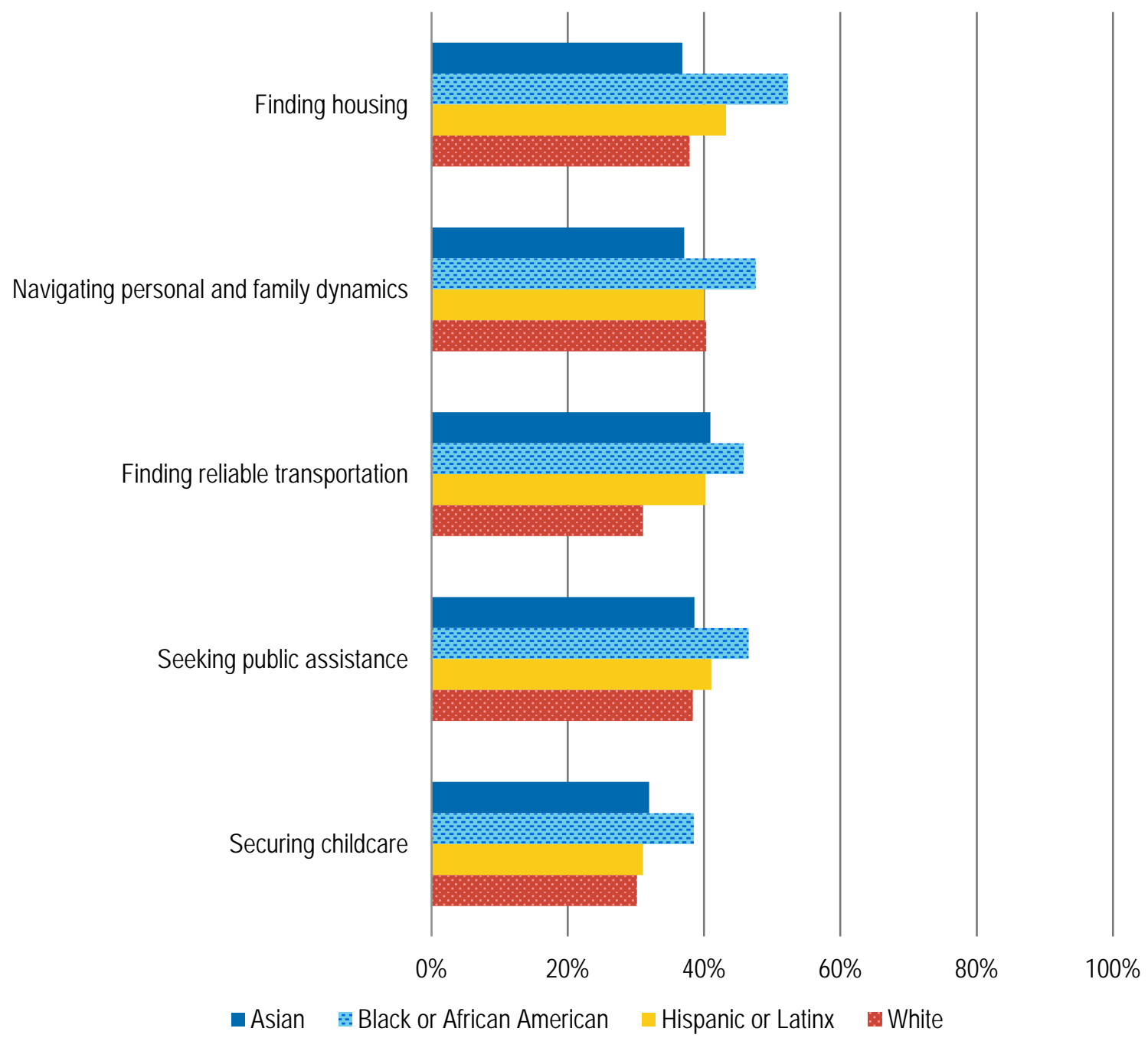

Although relatively fewer students would use a social worker for securing childcare compared to other uses, of those who are parents/guardians, five in ten would value a social worker's assistance. Not only would parents and guardians value a social worker providing assistance in seeking childcare, but about 51 percent would find the Child Care service concept extremely valuable as well. The following discussion only pertains to respondents who are a parent/guardian of a dependent minor. ${ }^{14}$

\footnotetext{
${ }^{14}$ Overall, 25 percent of respondents - including those who are and who are not parents/guardians - indicated the Child Care service concept as extremely valuable (see Appendix B). While parents/guardians may not be the only students responsible for seeking childcare, they are highlighted in our reporting, as they are most likely to be responsible for it.
} 
The Child Care service concept would be particularly more valuable to women than men, with 55 percent of women rating this service as extremely valuable compared to 36 percent of men. This service is also more highly valued by parents/guardians in their twenties and thirties: 65 percent of respondents within the 23-30 age cohort indicated this service concept as extremely valuable, followed by 53 percent of those aged 31-40, 44 percent aged 18-22, and 34 percent aged 41 and older. This may be a reflection of the age of the children of these respondents, though we did not gather these data. Additionally, approximately 58 percent of black or African American students find this service concept extremely valuable, followed by 56 percent of Hispanic or Latinx students, 45 percent of white students, and 43 percent of Asian students.

Parents and guardians who indicated this service as extremely valuable would prefer these childcare services to be offered during the day, particularly on weekdays, but would also highly value these services in the evenings and on weekends. About 72 percent would value these services on the weekdays, followed by 68 percent during the daytime, 64 percent during the evening, and 56 percent during the weekends. Childcare services provided during the day would be more valuable to those enrolled full time at their college than those enrolled part time: 72 percent of full-time enrolled parents/ guardian students value this service during the day compared to 61 percent of part-time enrolled students. However, the value of daytime childcare services does not differ by the format of their courses. Those enrolled in person, online, and both in person and online rate daytime childcare services as extremely valuable (see Figure 9). Interestingly, respondents enrolled online would value childcare services on the weekends notably more so than students enrolled in person, and students enrolled both in person and online, perhaps because those enrolled online complete their coursework on the weekends. 
Figure 9. How valuable would this service be for you during the following days and times? Percent of respondents by enrollment in person, online, or both that indicated each time period as extremely valuable.

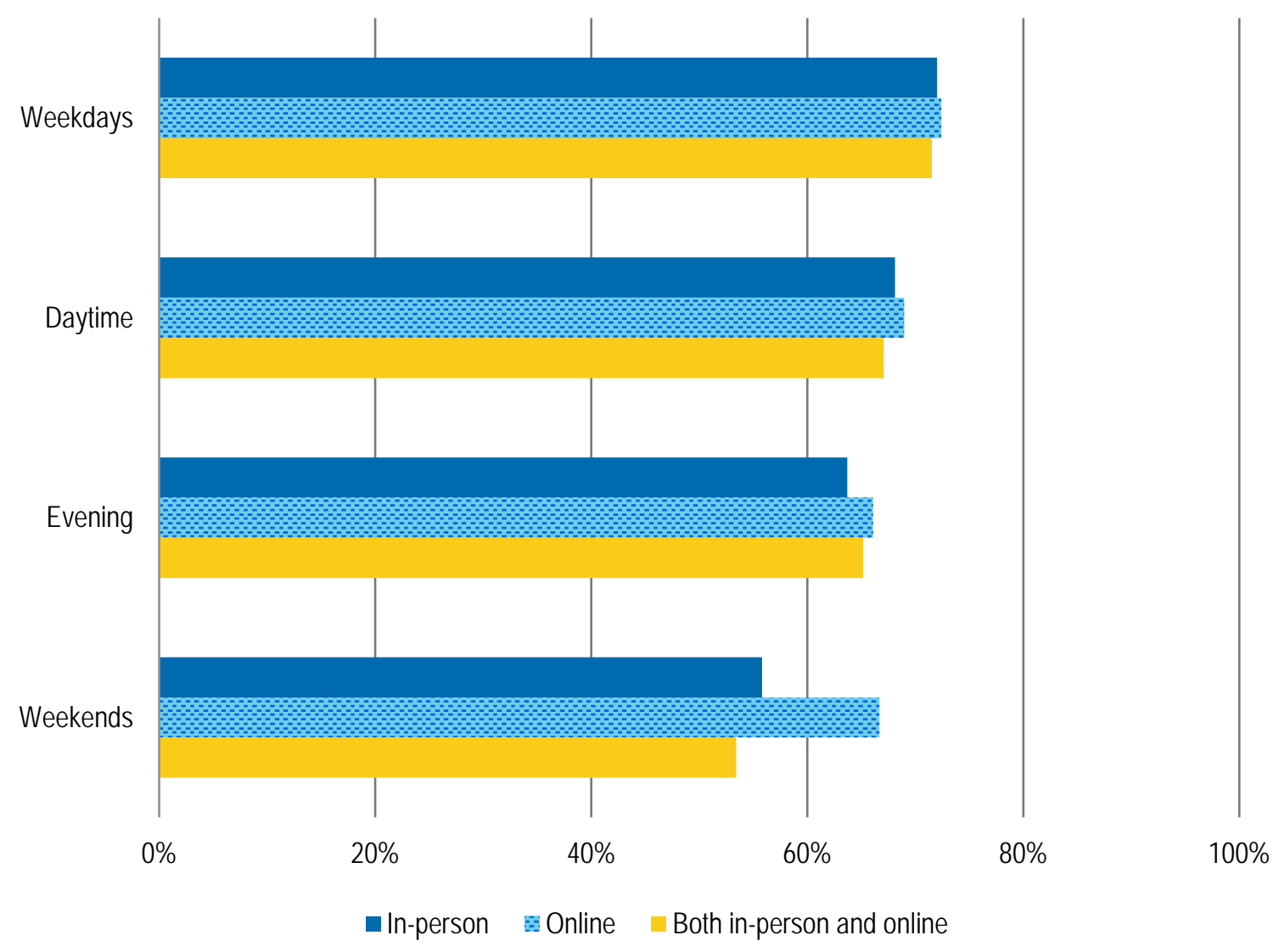

Parents and guardians of dependent minors would value many types of childcare services provided by their community college: 75 percent indicated they would benefit from both regular childcare and emergency childcare, 69 percent from tutoring or afterschool services, and 63 percent from designated space for families to study. Parents and guardians would frequently use these services if provided - 62 percent indicated they would use this service more than twice a week. When asked where they would be more likely to use these services, approximately 77 percent named the library, followed closely by the tutoring/ writing center ( 76 percent). About seven in ten respondents also indicated they would be more likely to use this service if offered at a one-stop center, academic advising office, or career/job placement office. 


\section{Technological Needs}

The second highest valued service concept was Loaning Tech, which would provide students with the opportunity to borrow and access different types of technological software and/ or hardware for use inside or outside of class, or at home, with individuals available for assistance in using these tools. Notably, while 42 percent of students rated Loaning Tech as extremely valuable, less than 10 percent of respondents said that having reliable access to technology was difficult. Having access to technological materials, however, is not necessarily sufficient. As one student indicated in our earlier interviews, "I have a [laptop] but the battery, it's damaged, so it's [just] in the corner. I don't use it." In order to reduce the financial burdens that so many students have reported, it is essential that they not only have access to technology but that it is functional and affordable.

Loaning Tech: Imagine that there was a place at your college where you could access technology either to borrow for use outside class and at home, or use on-site with expert training and assistance. The equipment available might include options such as a 'onetouch studio' for recording video presentations, 3-D printers, large-format poster-size printers, virtual reality headsets, multimedia editing computers and software, digital audio/video recorders, laptops, tables, chromebooks, scientific calculators, Wi-Fi hotspots, and black/ white or color printers for on-site use and/ or checkout.

When asked what types of materials they would find particularly useful to borrow or use, eight in ten students named Wi-Fi hotspots, followed by black/ white or color printers (74 percent), laptops ( 71 percent), and multimedia editing computers or software (60 percent). There were no substantial differences in the perceived value of borrowing $\mathrm{Wi}$ Fi hotspots across respondent subgroups, indicating that this resource would be valued widely by a large share of students. Students who rated this service as extremely valuable would want to borrow or use them for a considerable amount of time (i.e. a semester) or for a relatively short period of time (i.e. a few hours), depending on the specific technology (see Figure 10). 
Figure 10. For approximately what length of time would you want to borrow or use each of the following technologies? Percent of respondents that indicated the Loaning Tech service concept as extremely valuable.

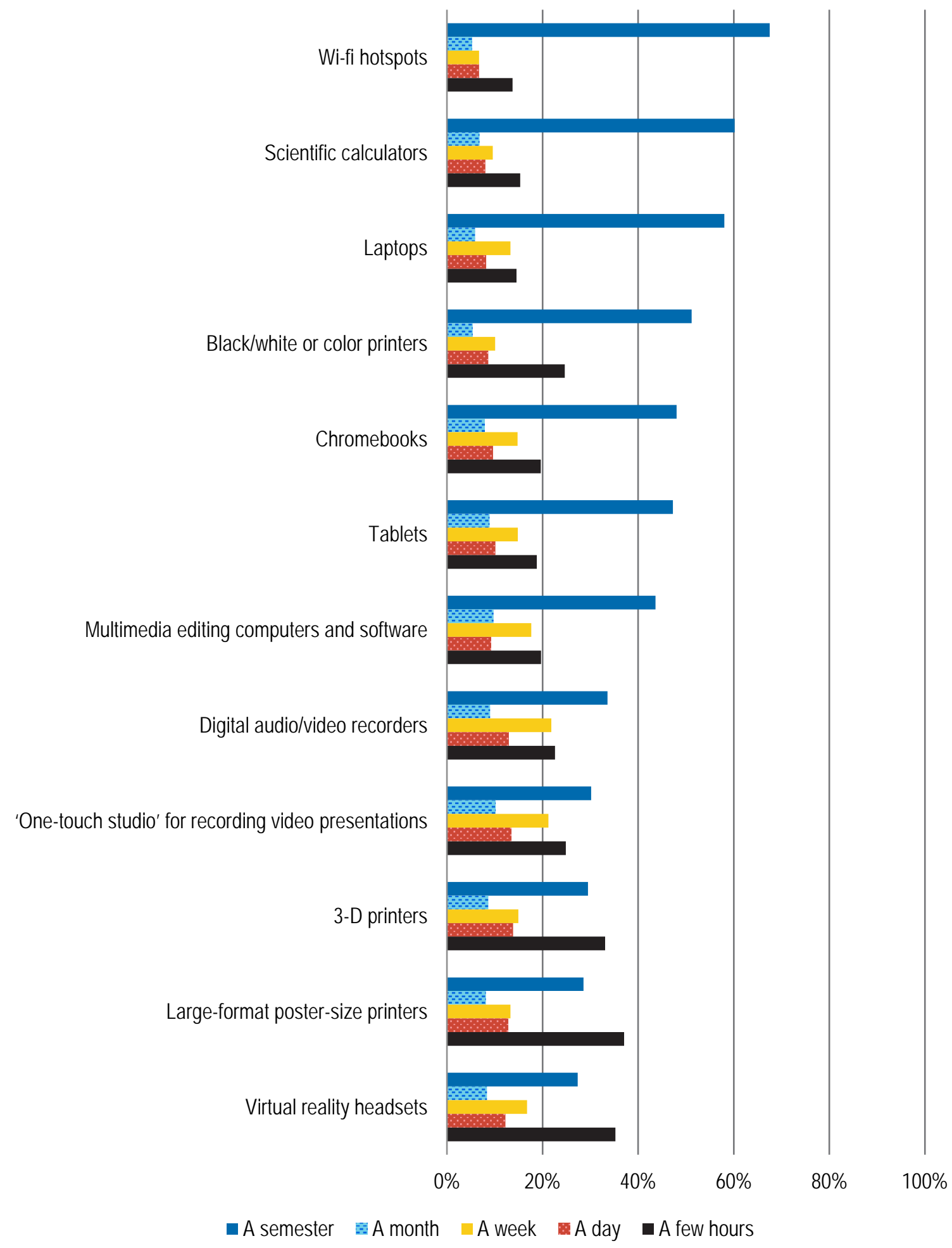


These technologies would be particularly valuable for those who are enrolled in person, are Pell-eligible, and/ or identify as black, African American, Hispanic, and/ or Latinx. About 43 percent of students who are enrolled in person, as well as those enrolled both in person and online, value this service compared to 36 percent of those enrolled solely online; students enrolled online may not value this service as readily as those enrolled in person due to the likelihood of needing to come to campus to use or borrow technology. Additionally, 47 percent of those who are Pell-eligible find this service particularly useful compared to 36 percent of their peers. Lastly, about five in ten black, African American, Hispanic, and/ or Latinx students rate this service as extremely valuable followed by about four in ten Asian students, and about three in ten white students.

Students would use this service for both coursework and non-coursework activities: 77 percent of respondents who see this service as extremely valuable rate it as very useful for academics and/ or coursework, 69 percent for career/ professional purposes, and 60 percent for personal reasons. About 84 percent of respondents would be more likely to use this service if it were provided at their library, followed by their college's student computer labs, IT helpdesk, or IT office (80 percent), tutoring/ writing center (73 percent), and one-stop center (69 percent).

Conversely, a relatively small share of students (24 percent) rate the Privacy service concept, which would provide workshops on how to operate technology effectively and safely, as extremely valuable. Students are substantially more interested in borrowing and using technology than they are in learning about maintaining their privacy when using it. Of the students who rated the Privacy service as extremely valuable, approximately 65 percent would be interested in attending the workshop in person compared to 36 percent preferring online. Of those who would find this service extremely valuable, 77 percent would be more likely to attend if offered by their college's computer labs, IT helpdesk, or IT office, 74 percent if at their library, and 67 percent if at their academic advising office or tutoring/ writing center.

Privacy: Imagine that there was a workshop you could take about how to operate effectively and safely in today's digital world. This would include a practical guide on how to choose which digital services to use, how to encrypt sensitive communications, and how to delete your activity trail and presence. Each student would be guided in finding the right balance between using personalized services and the privacy interests that these services may minimize. 


\section{Programming Needs}

The service concepts of Community Advocacy and Student Showcase would provide opportunities for students to get involved in their communities, gain skills relevant to their interests, and exhibit their work outside of the classroom. These types of programs would provide students with resume-building experiences and opportunities to develop a professional network outside of their professors, college administrators, and peers; these objectives were identified as being highly important as reported above. However, only about two in ten students find these two prospective services to be extremely valuable.

Community Advocacy: Imagine the college made available opportunities that would help you better develop your capacity as a member of your community and society. These could include one-time presentations by faculty, members of community groups, industry experts, or fellow students, and could take the form of workshops, ongoing discussion groups, informal meetups, or online resources. Rather than seek to educate you on particular political perspectives, the goal would be to help you develop your own perspective and strategies for engagement, so you could participate on issues that are important to you as a citizen, an informed member of society, an activist, or whatever other role you choose to assume.

Student Showcase: Imagine that the college offered you and fellow students an opportunity to publicly display work from your classes, or to contribute personal and professional expertise developed outside of classes, through various displays, presentations, workshops, and more, either in person or virtually. You would have a space in which you could gather with other students to share your experience, expertise, and work, as well as learn from other students.

For those who would find these services extremely valuable, most would prefer in-person programming. About seven in ten students who rated Student Showcase as extremely valuable would find an in-person format useful compared to three in ten who would prefer an online format. Five in ten would value Community Advocacy services through both online resources and in-person workshops; approximately four in ten rate discussion groups, presentations, and informal meetups as extremely valuable for these workshops.

When asked who they would like to participate within Community Advocacy programming, 62 percent named industry experts, followed by 52 percent for faculty members, and 50 percent for peers/ fellow students and community groups. Although this service concept was described as a service to help students develop their capacity as a member of their community and society, and to participate on issues that are important to them as a citizen, students would rather have industry experts compared to community-focused individuals or groups. As 48 percent of students rate building their resume with career-related experiences as an extremely important goal, and 43 percent 
similarly value developing a professional network, it is perhaps unsurprising that students prefer programming that helps them to connect with industries that align with their career interests.

When asked how often they would use these service concepts, about a third of students that rated each as highly valuable indicated more than twice a week (see Figure 11). Further, students would be most likely to use these program-based services if provided by their library. Eight in ten students would be more likely to use Community Advocacy services at their library or career/job placement office, followed by their academic advising office ( 77 percent), one-stop center ( 76 percent), or tutoring/ writing center (74 percent). Similarly, eight in ten students would be more likely to use Student Showcase if offered by their library, followed by their tutoring/ writing center or career/job placement office ( 75 percent), academic advising office ( 74 percent), or student life office (71 percent).

Figure 11. How often would you use this service? Percent of respondents that indicated each service concept as extremely valuable.

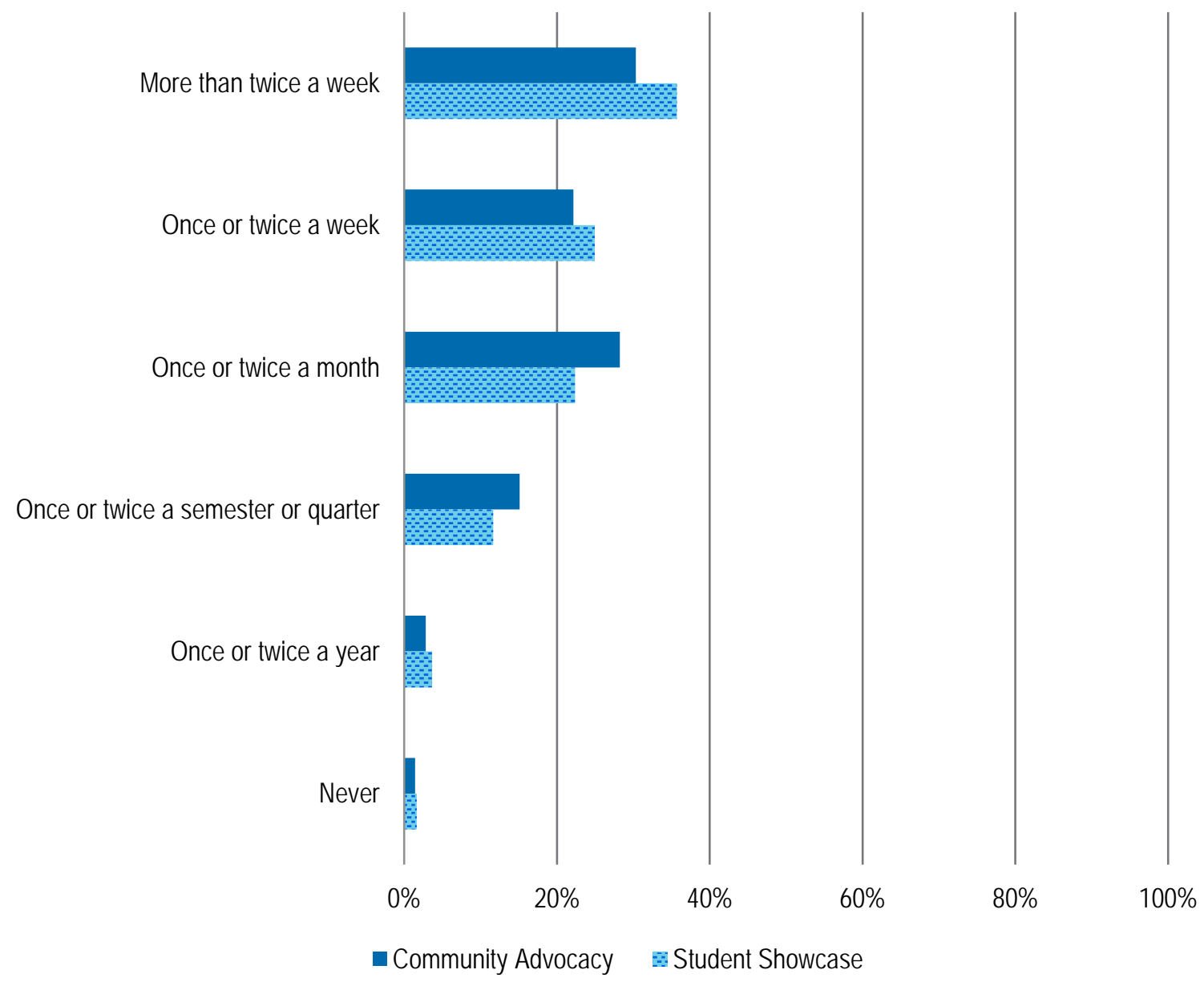




\section{Final Thoughts}

In our earlier report on the CCLASSS project, "Amplifying Student Voices," qualitative interviews with community college students from the partner colleges illuminated that today's students have complex definitions of success that focus on both their career and educational achievement as well as their personal development. ${ }^{15}$ As one student so clearly articulated, "I mean, yeah, the degree is cool, but I'm more about the knowledge." Consistent with earlier findings, this large-scale survey affirms that community students prioritize learning and mastery along with instrumental goals such as increased earnings and choosing a post-graduation career.

However, students come to college with a significant portfolio of personal and academic challenges that may prevent them from achieving these goals. Half of the surveyed students report substantially struggling to balance their home and work responsibilities with their academics and encountering financial challenges in paying for their courses and basic needs. However, these challenges are not uniformly distributed - they vary based on age, ethnicity, and Pell Grant status, among others - with students from historically underserved and disadvantaged groups displaying increased challenges compared to their peers. As such, we would encourage colleges and their libraries to consider customized approaches to the services they offer.

Although the survey was not presented to respondents as a library-led project, when the library was displayed in context as one of a range of potential service providers, students most often view the library as the service provider they would likely go to for these services. This demonstrates that students see the library not only as an informational resource, an academic resource, or simply as a quiet place to study, but also as a community resource within the campus context. Libraries that focus too narrowly on their academic role alone may be missing greater opportunities for more communityoriented services and outreach. In light of this, the partner college libraries engaged in this project are thinking ever more broadly regarding their role and are seeking to provide services and programming more inclusively than has traditionally been the case.

These findings affirm that libraries can and do play an essential role in student success initiatives. However, library contributions towards student success initiatives may belost or unheard when they are not seen as potential contributors to student success by administration, and those in academic administration may want to think more inclusively of the libraries on their campuses. Including libraries as part of the

${ }^{15}$ Christine Wolff-Eisenberg and Braddlee, "Amplifying Student Voices: The Community College Libraries and Academic Support for Student Success Project," Ithaka S+R,13 August 2018, https://doi.org/10.18665/sr.308086. 
institutional team to help remove barriers for curricular and non-curricular challenges, will also require libraries to be provided with sufficient resources in onder to succeed. Adding new responsibilities, services, or programming without additional funding or staffing in an already resource constrained environment can prove difficult.

In the next stage of this project, each of the partner colleges has agreed to pilot one or more of the service concepts tested in the survey, based on the needs expressed by their college's respondents as well as resources available for implementation. These pilots represent an opportunity to engage and collaborate with other areas of the institution writing centers, student services, technology, and faculty - in new ways. An upcoming report will share these experiences, along with the opportunities and challenges they have presented for the participating libraries.

Additionally, a project toolkit, including the survey instruments, guidelines for adoption and adaptation, and the survey dataset for purposes of benchmarking and comparison, will be made available in the coming months. These materials will be able to be adopted and modified for use by institutions who do not have deep pockets to support research.

This project has gleaned important insights on the goals, challenges, and needs of community college students relating not only to the library but to other units of the institution as well. This, however, is simply one step in an ongoing journey of research and assessment to support evidence-based innovation and change in libraries and librarianship in community college and in the broader higher education ecosystem as well. We look forward to continuing our collaborations with these communities and sharing additional resources to support this work. 


\section{Appendix A: Demographic Table}

\begin{tabular}{|c|c|c|c|}
\hline \multicolumn{2}{|c|}{ Population Demographic } & \multirow{2}{*}{$\frac{\text { Frequency }}{7,300}$} & \multirow{2}{*}{$\begin{array}{l}\text { Percentage }^{16} \\
69 \%\end{array}$} \\
\hline Enrollment Status & Enrolled Full Time & & \\
\hline & Enrolled Part Time & 3,345 & $31 \%$ \\
\hline \multirow{3}{*}{$\begin{array}{l}\text { Enrollment } \\
\text { Type }\end{array}$} & Enrolled In Person & 7,372 & $69 \%$ \\
\hline & Enrolled Online & 714 & $7 \%$ \\
\hline & Both In Person \& Online & 2,573 & $24 \%$ \\
\hline \multirow{5}{*}{$\begin{array}{l}\text { Days/Times } \\
\text { Currently Enrolled } 17\end{array}$} & Daytime & 7,506 & $69 \%$ \\
\hline & Evening & 4,819 & $44 \%$ \\
\hline & Weekdays & 5,327 & $49 \%$ \\
\hline & Weekends & 1,306 & $12 \%$ \\
\hline & All classes are online & 666 & $6 \%$ \\
\hline \multirow{4}{*}{$\begin{array}{l}\text { Employment } \\
\text { Status }^{18}\end{array}$} & Full-Time Job (on campus) & 417 & $4 \%$ \\
\hline & Full-Time Job (off campus) & 3,012 & $28 \%$ \\
\hline & Part-Time Job (on campus) & 1,114 & $10 \%$ \\
\hline & Part-Time Job (off campus) & 4,387 & $40 \%$ \\
\hline
\end{tabular}

\footnotetext{
${ }^{16}$ Percentages may not total 100 percent due to rounding or format of question; multi-select questions have been identified in subsequent footnotes.

${ }^{17}$ Respondents were able to select more than one option for this question; percentages calculated out of total number of survey respondents.

${ }^{18}$ Respondents were able to select more than one option for this question; percentages calculated out of total number of survey respondents.
} 


\begin{tabular}{|c|c|c|c|}
\hline \multirow[t]{5}{*}{ Transfer Status 19} & $\begin{array}{l}\text { Attended another college or university } \\
\text { where I earned another degree and/or } \\
\text { credential }\end{array}$ & 1,767 & $16 \%$ \\
\hline & $\begin{array}{l}\text { Attended another college or university } \\
\text { where I did not earn another degree } \\
\text { and/or credential }\end{array}$ & 1,887 & $17 \%$ \\
\hline & $\begin{array}{l}\text { Transferred credits from another college or } \\
\text { university to my current college }\end{array}$ & 2,701 & $25 \%$ \\
\hline & $\begin{array}{l}\text { Considered transferring to another college } \\
\text { or university without earning my current } \\
\text { degree and/or credential }\end{array}$ & 1,551 & $14 \%$ \\
\hline & $\begin{array}{l}\text { Considered transferring to another college } \\
\text { or university after earning my current } \\
\text { degree and/or credential }\end{array}$ & 4,665 & $43 \%$ \\
\hline \multirow[t]{3}{*}{ Gender Identity } & Woman & 7,090 & $66 \%$ \\
\hline & Man & 3,440 & $32 \%$ \\
\hline & Non-Binary20 & 138 & $1 \%$ \\
\hline \multirow{2}{*}{$\begin{array}{l}\text { Parent/Guardian } \\
\text { Status }\end{array}$} & Parent/Guardian of Dependent Minor & 2,421 & $23 \%$ \\
\hline & Non-Parent/Guardian of Dependent Minor & 8,226 & $77 \%$ \\
\hline \multirow{2}{*}{$\begin{array}{l}\text { Born in the United } \\
\text { States }\end{array}$} & Born in the US & 7,290 & $68 \%$ \\
\hline & Not Born in the US & 3,385 & $32 \%$ \\
\hline
\end{tabular}

${ }^{19}$ Respondents were able to select more than one option for this question; percentages calculated out of total number of survey respondents.

${ }^{20}$ Respondents were able to fill in the gender they identify with if not listed. Within the survey instrument, this item appeared in the following way: "I don't identify with either of these. I identify as." 


\begin{tabular}{|c|c|c|c|}
\hline \multirow{7}{*}{$\begin{array}{l}\text { Race/Ethnicity } \\
\text { Identity }^{21}\end{array}$} & American Indian or Alaska Native & 237 & $2 \%$ \\
\hline & Asian & 1,763 & $17 \%$ \\
\hline & Native Hawaiian or Other Pacific Islander & 156 & $1 \%$ \\
\hline & Black or African American & 2,213 & $21 \%$ \\
\hline & Hispanic or Latinx & 3,079 & $29 \%$ \\
\hline & White & 3,730 & $35 \%$ \\
\hline & Other & 529 & $5 \%$ \\
\hline \multirow[t]{2}{*}{$\begin{array}{l}\text { Parent Education } \\
\text { Status }\end{array}$} & $\begin{array}{l}\text { Parent(s) completed college/university } \\
\text { degree }\end{array}$ & 4,662 & $44 \%$ \\
\hline & $\begin{array}{l}\text { Parent(s) did not complete } \\
\text { college/university degree }\end{array}$ & 5,953 & $56 \%$ \\
\hline \multirow[t]{2}{*}{ Military Status } & $\begin{array}{l}\text { Currently serving active duty or veteran of } \\
\text { the US Armed Forces, National Guard, or } \\
\text { Reserves }\end{array}$ & 512 & $5 \%$ \\
\hline & $\begin{array}{l}\text { Not currently serving active duty or } \\
\text { veteran of the US Armed Forces, National } \\
\text { Guard, or Reserves }\end{array}$ & 10,124 & $95 \%$ \\
\hline \multirow[t]{3}{*}{ Pell Grant Status } & $\begin{array}{l}\text { Received or currently eligible for Federal } \\
\text { Pell Grant }\end{array}$ & 4,780 & $45 \%$ \\
\hline & $\begin{array}{l}\text { Have not received or currently eligible for } \\
\text { Federal Pell Grant }\end{array}$ & 2,617 & $25 \%$ \\
\hline & $\begin{array}{l}\text { Don't know/Not sure if received or } \\
\text { currently eligible for Federal Pell Grant }\end{array}$ & 3,269 & $31 \%$ \\
\hline \multirow[t]{4}{*}{ Age Cohort } & 18 to 22 years old & 5,152 & $50 \%$ \\
\hline & 23 to 30 years old & 2,866 & $28 \%$ \\
\hline & 31 to 40 years old & 1,372 & $13 \%$ \\
\hline & 41 years old and older & 918 & $9 \%$ \\
\hline
\end{tabular}

${ }^{21}$ Respondents were able to select more than one option for this question; percentages calculated out of total number of survey respondents. 


\section{Appendix B: Service Concept Valuation}

How valuable would this service be for you? Percent of respondents that indicated each as not at all, not too, somewhat, very, or extremely valuable.

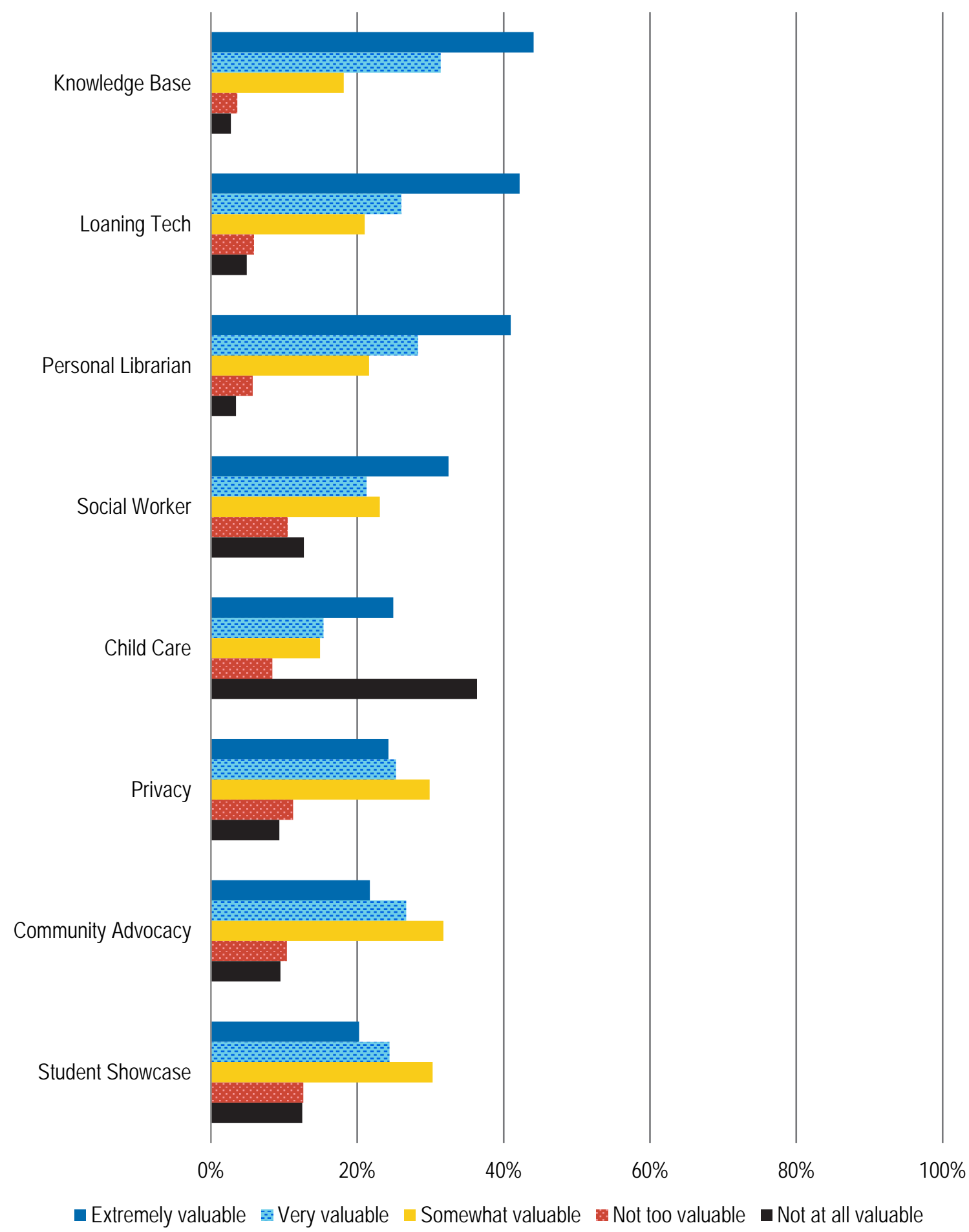

